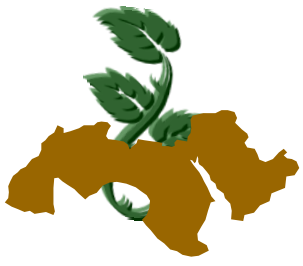

Arab Univ. J. Agric. Sci., Ain Shams Univ., Cairo, 23(1), 3 - 11, 2015

\title{
RESPONSE OF SNAP BEAN PLANTS TO SOME AGRICULTURAL TREATMENTS FOR EARLY YIELD PRODUCTION
}

\author{
Nahed, M.M. El-Shimi ${ }^{1}$
}

1- Self-Veg. Cro. Res. Dept., Hort. Res. Inst., Agric. Res. Cen., Giza, Egypt

Keywords: Snap bean, Foliar nutrition, Protection plants, Early yield

\section{ABSTRACT}

Two field experiments were carried out during two early summer seasons of 2012 and 2013 years at the Experimental Farm of Kaha Station, Qalubia Governorate to study the response of snap bean plants Poulista c.v to some agricultural treatments for early green pods yield production using (flowering, amcotone, super phosphate solution compounds) as foliar nutrition, (charcoal, agriculture sulphur and charcoal + agriculture sulphur) as soil addition and( Pea, onion and broad bean) as protection plants, in addition using black polyethylene plastic as a soil mulch. The results indicated that spraying the plants with flowering and amcotone compounds followed by super phosphate solution had the highest values of fresh and dry plant weight. While adding charcoal to the soil before sowing snap bean seeds gave the highest values of no. of leaves/ plant followed by spraying with flowering and amcotone compounds, respectively. The data showed also that spraying the plants with flowering, amcotone compounds, super phosphate solution, adding charcoal + sulphur and soil mulch with black polyethylene plastic exerted the highest values on all parameter of green pods its and yield attributes in both growing seasons. Concerning total sugars in dry pods it's clear that using protection plants with broad bean followed by onion were the best treatments on it. Generally it can recommend using any one of the mentioned treatments in this experiment especially flowering, amcotone compounds, super phosphate solution, charcoal + sulphur, respectively to obtain high green pod yield either early or total with the best quality.

\section{INTRODUCTION}

Snap bean plants (Phaseolus vulgaris L.) are considered one of an important vegetable crops cultivated in Egypt for local market and exportation. It is known that, bean plants are relatively sensitive to environmental stresses specially high and low temperature, that may occur in the field which negatively affect its growth, yield and even the quality of pods. The optimum temperature range for optimum bean growth or pod yield is between 16- $30^{\circ} \mathrm{C}$ (Nonnecke, 1989) .In addition, temperature below or above this range had deleterious effects on plant performance as well as green pod yield. Seeds germination perhaps failing or might be delaying at temperature below $10^{\circ} \mathrm{C}$ as found by Poincelot (1980) Many investigators indicated that bean plants are very sensitive to different environmental stresses such as chilling (El-Tohamy et al 2001, Singer et al 1996) drought (Millar and Gardner, 1972; Halterlein, 1983; ElTohamy et al1999) and heat stress Dale, (1964). Hence, improving tolerance of bean plants to the possible environmental stresses by using different treatments is important to enhance its growth, maximize the yield and its quality.

Flowering and Amcotone compounds contain Naphthyl acetic acid (NAA) and Naphthyl acetamide it is known that, NAA could activate membrane $\mathrm{Ca}^{2}+$-ATP as activate better movement of $\mathrm{Ca}$. Banuelos et al (1988) reported that transport of calcium in tomato fruit is concerned with the basipetal transport of auxins. Moreover, NAA has also played main role in transport of $\mathrm{Ca}$ in Chinese cabbage (Wen et al 1991). Dong et al (2005) also suggested that spraying $\mathrm{CaCl}_{2}$ in combination with NAA to tomato plants for better Ca mobilization. Higher level of $\mathrm{CaCl}_{2}$ (1\%) with NAA $(0.02 \%)$ increased plant growth and yield by improving mineral uptake of tomato plants. Suty (1984) showed that, foliar application on faba bean plants with 
Rhodofix (NAA) increased yield. Moreover, Bai et al (1987) applied eight foliar sprays of $25 \mathrm{mg} / \mathrm{L}$ NAA at 7 days intervals on Vigna rediata led to significant increases in seed yield and yield components. Shukla et al (1997) on soybean and Aslam et al (2010) on chickpea concluded that spray of growth regulators enhanced the number of pods per plant, pod weight per plant and gave higher seed yield over the control. Deotale et al (1998) studied the effect of foliar spraying with GA and NAA on growth parameters of soybean and obtained highest values for plant height and number of leaves per plant with adding $100 \mathrm{mg} / \mathrm{L}$ NAA.

Plant charcoal, or biochar, is consider pure carbon and it is useful as a soil additive for vegetables, flowers and potted plants. Biochar helps on allowing better uptake of nutrients and fertilizers added to the soil for vigor plants and greater yields of trees fruits, vegetables and blooms on plants. It is a manufactured product but is all natural and prepare from green waste products, such as tree trimmings. Biochar is a rich carbon product formed by the incomplete combustion of biomass, has been shown to improve soil quality and increase crop growth. Studies have shown significant increases in the availability of all major cations (Glaser et al 2002 and Topoliantz et al 2005). Moreover, Graber et al (2010) and Altland and Locke (2012) demonstrated that additions of biochar up to $10 \%$ by volume decreased peak nitrate and phosphate leaching by slowing their release over time. This suggests nitrate could be applied less frequently due to the capacity of biochar to hold nitrate and release it to the plant roots slowly.

Regarding to soil mulches at early spring plantation or in winter for early yields, it is known that black polyethylene plastic mulch is the standard plastic mulch used in vegetable production, the importance of usage polyethylene mulch is due to its benefits when covering soil surface before sowing to recognize greater benefits, i.e. increases soil temperature, especially in early spring, reduces weed problems, enhances moisture conservation, increases crop yields and leads to more efficient use of soil nutrients (Berihun, 2011; Bhatt et al 2011; Hatami et al 2012; Kumar and Lai, 2012).

Concerning using super phosphate solution it is known that, Phosphorus is absorbed in the form of phosphate ions, $\mathrm{H}_{2} \mathrm{PO}^{-}{ }_{4}$ and $\mathrm{HPO}_{4}^{-}$. It is an essential constituent of lipo- protein membranes of cell, nucleoproteins, many co-enzymes and organic molecules such as ADP, ATP and NADP which play an important role in the energy transfer reactions of cell metabolism and in oxidation, reduction reactions. (Kochhar and Krishnamoorthy, 1988). It is also necessary for the functioning of mitochondria, which are the centers of cellular respiration. Shafeek et al (2005) found that all parameters of plant growth, total yield and yield components as well as the chemical composition of green pea seeds tissues recorded the highest significant values with applying the chemical sources of phosphorus and potassium fertilizers compared with the natural source alone. Moreover, ElTohamy et al (2006) indicated that additional foliar application of nutrients especially by phosphorus, calcium and potassium can improve growth and yield of pepper plants grown under sandy soil conditions during winter season, the reduction of the electrolyte leakage in response to foliar application of $\mathrm{P}, \mathrm{Ca}$ and $\mathrm{K}$ during low temperature conditions could be an indirect effect on reducing plant tissue dehydration caused by chilling which resulted in higher plasma membrane stability.

Regarding to sulphur, it has an important role in the formation of plant proteins and some hormones, as well as being necessary for enzymatic action, chlorophyll formation, and synthesis of certain amino acids and vitamins (Kundu and Gaur, 1984 and Monib et al 1984). Hence, sulphur is important for good vegetative growth leading to a high yield and increasing absorption of macro and micronutrients. This is through its oxidation to sulphuric acid by soil microorganisms leading to the solubilization and availability of nutrients to plants crops. (Marschner, 1998; Salem, 2003 and Salem et al 2004).

It is obvious that, sowing bean plants under the protection methods with maize and sunflowers Turky (2007) and Abdel-Aziz and Gaafer (2013), cowpea and maiz Dahmardeh et al (2010) and Eskandari et al (2012) as protection plants significantly increases in growth characteristics, pod yield and some chemical properties i.e. nitrogen, phosphorus and potassium (\%) when compared with the control unprotected plant .

Therefore, the aim of this investigation was to study the response of snap bean plants grown in early summer season to some agricultural treatments for obtained early green pod yield with the best quality.

\section{MATERIALS AND METHODS}

The present work was carried out during two early summer successive seasons of 2012 and 2013 at the Experimental Farm, Kaha Station, 
Qalubia Governorate. Soil was clay in texture with 7.2 ph, 3.5 EC $1.15 \%$ organic matters, 110 ppm N, 49 ppm P and 103 ppm K. Seeds of snap bean cv . Poulista were obtained from Horticultural Research Institute, Agriculture Research Center, Egypt .The climatic condition ,i.e. temperature and relative humidity during plantation period are shown in Table (1).

The experiment was carried out in complete randomized block design with three replicates. The seeds of snap bean were sown on January $8^{\text {th }}$ and $2^{\text {nd }}$ in 2012 and 2013, respectively in hills on one side of ridges at $7 \mathrm{~cm}$ spaces. The area of each experimental plot was $8.4 \mathrm{~m}^{2}$ and consisted of 3 ridges ( $4 \mathrm{~m}$ long with $0.70 \mathrm{~m}$ width).

The experiment contained eleven treatments as the following:
T1- Control

T2 - Flowering T3- Amcotone T4- Super phosphate solution

(T2, T3and T4) as foliar nutrition.

T5- Pea T6- Onion T7- Broad bean

(T5, T6 and T7) as plant protection.

T8- Black Polyethylene plastic mulch (BP Mulch). As soil mulch.

T9 - Charcoal (3t/fed)

T10- Agriculture sulphur $(250 \mathrm{~kg} / \mathrm{fed})$

T11- Charcoal + agriculture sulphur with the same rates

(T9, T10 and T11) as soil application.

Compounds (flowering, amcotone, super phosphate solution) were used as foliar nutrition for the purpose of enhancing pod setting and for cold tolerant. Plants were sprayed three times with aqueous solution of the used materials, the first spray was conducted at the three true leaves stage, whereas the second and third spray were preformed 10 days intervals. Pea, onion and broad bean were sown on the other side of ridge as protection plants. Charcoal and agriculture sulphur were mixed with the soil before sowing during soil preparation.

Table 1. Climatic condition at the experimental sites during periods of studies (Central Laboratory for Agricultural Climatic)

\begin{tabular}{|c|c|c|c|c|c|c|c|}
\hline Month & \multicolumn{2}{|c|}{ Temperature(Co) } & \multirow{2}{*}{$\begin{array}{c}\text { Relative } \\
\text { humidity } \\
\%\end{array}$} & \multirow{2}{*}{$\frac{\text { Month }}{2013}$} & \multicolumn{2}{|c|}{ Temperature(Co) } & \multirow{2}{*}{$\begin{array}{c}\text { Relative } \\
\text { Humidity } \\
\%\end{array}$} \\
\hline 2012 & Minimum & Maximum & & & Maximum & Minimum & \\
\hline January & 1.48 & 21.93 & 75 & January & 0.74 & 24.81 & 77 \\
\hline February & 3.37 & 20.74 & 69 & February & 1.74 & 26.26 & 75 \\
\hline March & 0.63 & 24.98 & 71 & March & 2.23 & 35.27 & 70 \\
\hline April & 7.18 & 37.72 & 66 & April & 6.1 & 36.82 & 65 \\
\hline May & 11.8 & 38.54 & 62 & May & 11.47 & 40.75 & 59 \\
\hline
\end{tabular}

Table 2. Spray compounds and its contents of the foliar nutrition compounds used in this study

\begin{tabular}{|lll|}
\hline Compounds name & \multicolumn{1}{c|}{ Composition } & \multicolumn{1}{c|}{ Concentration } \\
\hline Flowering & $\begin{array}{l}\text { Naphthyl acetic acid } 1.5 \%, \\
\text { Naphthyl acetamide } 0.3 \% \\
\text { and other additives } 97.9 \%\end{array}$ & $0.5 \mathrm{~g} /$ liter \\
\hline Amcotone & $\begin{array}{l}\text { Naphthyl acetic acid } 0.45 \%, \\
\text { Naphthyl acetamide } 1.25 \% \\
\text { and other additives } 98.3 \%\end{array}$ & $0.6 \mathrm{~g} /$ liter \\
\hline Super phosphate & $15.5 \% \mathrm{P}_{2} \mathrm{O}_{5}$ & $3 \mathrm{~g} /$ liter after socking 24 hours \\
\hline
\end{tabular}




\section{Data Recorded}

\section{I- Plant Growth Measurements}

Representatives samples of 3 plants were taken by random 70 days after sowing (at flowering stage), from each experimental plot for measuring the plant growth characters, as follows:

Plant length $(\mathrm{cm})$, number of leaves plants, total fresh weight and dry weight of plant (determined at $65^{\circ} \mathrm{C}$ for 72 hours using the standard methods as illustrated by A.O.A.C. (1990).

\section{II- Green Pod Yield and its attributes}

Random samples of 10 green pods at the second picking were taken (after 85 days from sowing) to determine the following data:

- Average pod length $(\mathrm{cm})$, Pod diameter $(\mathrm{cm})$, Average fresh pod weight $(\mathrm{g})$ and Average dry pod weight $(\mathrm{g})$.

- Early pod yield ton/fed as the first and second pickings (after 77-85 days from sowing) -Total pod yield ton/fed as the total pickings.

\section{III- Chemical properties}

\section{The following measurements were determined:}

Total leaf chlorophyll was measured using Minolta chlorophyll Meter SPAD- 501 as SPAD units.

Total protein\% : It was determined as nitrogen content of pod and converted to its equivalent protein content by multiplying $\mathrm{N}$ content $\times 6.25$ (A.O.A.C.1990)

Total nitrogen, phosphorus and potassium were determined in dry pods on the basis of dry weight according to the methods described by Bremner and Mulvaney (1982), Olsen and Sommers (1982) and Jackson (1967), respectively.

Total sugars: It was determined on the basis of pod dry matter, calorimetrically using spectrophotometer with the phenol sulphuric acid method described by Dubois et al (1975)

Statistical Analysis: All data were subjected to statistical analysis according to the procedures reported by Snedecor and Cochran (1982) using $M$. stat program and means were compared by L.S.D multiple range tests at the $5 \%$ level of probability in the two seasons of experimentation.

\section{RESULTS AND DISCUSSION}

\section{I- Plant Growth Measurements}

Results of Table (3) illustrated that, spraying of flowering or amcotone compounds followed by the treatment of super phosphate solution had the highest values of fresh and dry plant weight. While, adding charcoal to the soil before sowing snap bean seeds gave the highest values of no. of leaves/ plant followed by spraying of flowering and amcotone compounds, respectively. Regarding to plant length, data indicated that treatments used in this study did not induce any significant effect in both growing seasons. It is clear that, the lowest values of vegetative growth parameters of snap bean plants were recorded by the control treatment. These results are in agreement with those obtained by Dong et al (2005) on tomato, they indicated that higher level of $\mathrm{CaCl} 2(1 \%)$ or NAA $(0.02 \%)$ increased plant growth by improving minerals uptake of tomato plants. Moreover, Deotale et al (1998) on soybean studied the effect of GA and NAA on growth parameter of soybean and they obtained the highest values of plant height and number of leaves per plant by $100 \mathrm{mg} / \mathrm{L}$ NAA treatment. Charcoal has been shown to improve soil quality and increase crop growth in addition; the studies have shown significant increases in the availability of all major cations as mentioned by (Glaser et al 2002 and Topoliantz et al 2005).On the other hand, El-Tohamy et al (2006) indicated that additional foliar application of nutrients especially by phosphorus, calcium and potassium can improve growth of pepper plants.

Regarding using the plant protection treatments with broad bean, pea and onion, it is clear that these treatments did not show significant effect on both parameters of plant growth as shown in Table (3). On the contrary, using black polyethylene mulch led to significant increase on fresh and dry weight of snap bean plant during the two seasons as shown in Table (3). It is known that using plastic mulch induce many benefits for plant growth by the way of increases soil temperature, especially in early spring, reduces weed problems, enhances moisture conservation, increases crop yields and leads to more efficient use of soil nutrients (Berihun, 2011; Bhatt et al 2011; Hatami et al 2012; Kumar and Lai, 2012).

\section{II- Green pod yield and its attributes}

The data in Table (4) showed that spraying snap bean plants with flowering, amcotone compounds, super phosphate solution, as well as 
Table 3. Effect of some agricultural treatments on vegetative growth of snap bean plants during the two seasons of 2012 and 2013

\begin{tabular}{|ccccccccc|}
\hline & $\begin{array}{c}\text { Plant length } \\
\text { Treatments }\end{array}$ & \multicolumn{2}{c}{$\begin{array}{c}\text { No. of. leaves } \\
\text { / plant }\end{array}$} & \multicolumn{2}{c}{$\begin{array}{c}\text { Fresh } \\
\text { weight } \\
\text { (g/plant) }\end{array}$} & $\begin{array}{c}\text { Dry } \\
\text { weight } \\
\text { (g/plant) }\end{array}$ \\
\cline { 2 - 9 } & $\mathbf{2 0 1 2}$ & $\mathbf{2 0 1 3}$ & $\mathbf{2 0 1 2}$ & $\mathbf{2 0 1 3}$ & $\mathbf{2 0 1 2}$ & $\mathbf{2 0 1 3}$ & $\mathbf{2 0 1 2}$ & $\mathbf{2 0 1 3}$ \\
\hline Control & 17.75 & 14.16 & 11.50 & 8.67 & 19.26 & 16.96 & 2.95 & 3.33 \\
Flowering & 24.66 & 22.16 & 17.50 & 15.50 & 35.38 & 32.76 & 6.78 & 6.45 \\
Amcotone & 24.16 & 22.00 & 17.22 & 14.00 & 33.53 & 31.16 & 7.31 & 6.61 \\
Super phosphate & 21.75 & 20.50 & 14.25 & 12.75 & 30.50 & 29.55 & 6.50 & 5.51 \\
Mulch & 20.66 & 23.66 & 14.00 & 15.00 & 28.01 & 29.21 & 5.50 & 5.85 \\
Pea & 19.87 & 19.87 & 13.75 & 12.00 & 23.25 & 22.92 & 4.55 & 4.32 \\
Onion & 20.25 & 18.56 & 15.25 & 12.33 & 24.87 & 26.20 & 4.61 & 4.37 \\
Broad bean & 19.83 & 18.16 & 13.00 & 14.17 & 24.65 & 23.12 & 4.12 & 4.10 \\
Charcoal & 21.16 & 17.66 & 19.33 & 11.61 & 26.71 & 24.91 & 6.31 & 4.30 \\
Sulphur & 21.16 & 19.33 & 14.39 & 13.00 & 27.65 & 23.98 & 6.32 & 4.95 \\
charcoal + sulphur & 23.00 & 20.50 & 13.44 & 13.37 & 26.79 & 23.49 & 6.40 & 5.08 \\
\hline L.S.D at 5\% & $\mathbf{N . S}$ & $\mathbf{N . S}$ & $\mathbf{4 . 2 5}$ & $\mathbf{N . S}$ & $\mathbf{7 . 3 5}$ & $\mathbf{3 . 9 5}$ & $\mathbf{2 . 0 5}$ & $\mathbf{1 . 2 4}$ \\
\hline
\end{tabular}

Table 4. Effect of some agricultural treatments on green pod yield and its attributes of snap bean plants during the two seasons of 2012 and 2013

\begin{tabular}{|cccccccccccccc|}
\hline & $\begin{array}{c}\text { Pod length } \\
\text { Treatments }\end{array}$ & \multicolumn{2}{c}{$\begin{array}{c}\text { Pod } \\
\text { diameter } \\
\text { (cm) }\end{array}$} & $\begin{array}{c}\text { Fresh pod } \\
\text { weight } \\
\mathbf{( g )}\end{array}$ & $\begin{array}{c}\text { Dry pod } \\
\text { weight } \\
(\mathbf{g})\end{array}$ & $\begin{array}{c}\text { Early yield } \\
\text { (ton/fed) }\end{array}$ & $\begin{array}{c}\text { Total yield } \\
\text { (ton/fed) }\end{array}$ \\
\cline { 2 - 14 } & $\mathbf{2 0 1 2}$ & $\mathbf{2 0 1 3}$ & $\mathbf{2 0 1 2}$ & $\mathbf{2 0 1 3}$ & $\mathbf{2 0 1 2}$ & $\mathbf{2 0 1 3}$ & $\mathbf{2 0 1 2}$ & $\mathbf{2 0 1 3}$ & $\mathbf{2 0 1 2}$ & $\mathbf{2 0 1 3}$ & $\mathbf{2 0 1 2}$ & $\mathbf{2 0 1 3}$ \\
\hline Control & 10.04 & 9.87 & 0.63 & 0.62 & 2.47 & 2.36 & 0.25 & 0.24 & 0.84 & 0.90 & 1.69 & 1.40 \\
Flowering & 11.80 & 12.55 & 0.65 & 0.66 & 4.08 & 4.46 & 0.33 & 0.34 & 1.90 & 1.80 & 3.83 & 3.63 \\
Amcotone & 11.78 & 11.68 & 0.64 & 0.65 & 3.80 & 3.84 & 0.35 & 0.33 & 1.80 & 1.76 & 3.61 & 3.44 \\
Super phosphate & 11.61 & 11.00 & 0.65 & 0.63 & 3.60 & 3.68 & 0.33 & 0.30 & 1.81 & 1.66 & 3.57 & 3.24 \\
Mulch & 11.47 & 11.93 & 0.63 & 0.64 & 3.53 & 4.04 & 0.32 & 0.32 & 1.55 & 1.62 & 3.01 & 3.12 \\
Pea & 10.84 & 11.06 & 0.63 & 0.64 & 3.22 & 3.37 & 0.32 & 0.31 & 1.67 & 1.18 & 2.86 & 3.01 \\
Onion & 10.75 & 11.01 & 0.62 & 0.63 & 3.27 & 3.57 & 0.29 & 0.28 & 1.46 & 1.39 & 3.00 & 3.05 \\
Broad bean & 10.42 & 10.54 & 0.63 & 0.63 & 3.06 & 3.13 & 0.27 & 0.26 & 1.02 & 1.13 & 2.39 & 2.37 \\
Charcoal & 11.15 & 10.74 & 0.63 & 0.61 & 3.39 & 3.33 & 0.30 & 0.31 & 1.38 & 1.27 & 3.03 & 3.07 \\
Sulphur & 11.16 & 11.31 & 0.63 & 0.64 & 3.45 & 3.36 & 0.31 & 0.31 & 1.61 & 1.55 & 3.16 & 2.93 \\
charcoal + sulphur & 11.21 & 11.43 & 0.63 & 0.67 & 3.54 & 3.67 & 0.33 & 0.32 & 1.70 & 1.59 & 3.19 & 3.11 \\
\hline L.S.D at 5\% & $\mathbf{0 . 8 0}$ & $\mathbf{0 . 7 4}$ & $\mathbf{0 . 0 5}$ & $\mathbf{N . S}$ & $\mathbf{0 . 6 2}$ & $\mathbf{0 . 4 2}$ & $\mathbf{0 . 0 5}$ & $\mathbf{N . S}$ & $\mathbf{0 . 3 4}$ & $\mathbf{0 . 2 8}$ & $\mathbf{0 . 6 7}$ & $\mathbf{0 . 7 2}$ \\
\hline
\end{tabular}


adding charcoal + sulphur and mulching with black polyethylene plastic exerted the highest values of all parameter of yield and yield attributes in both growing seasons. On the contrary, the lowest early and total yield of snap bean were recorded by the control treatment. These results are in agreements with those obtained by Suty (1984) on faba bean, Bai et al (1987) on Vigna rediata, Shukla et al (1997) on soybean and Aslam et al (2010) on chickpea. They concluded that spraying growth regulators enhanced number of pods per plant, pod weight per plant and gave higher seed yield over the control. Shafeek et al (2005) found that total yield and yield components of pea recorded the highest significant values with applying the mineral sources of phosphorus and potassium fertilizers compared with the natural source alone. Moreover, El-Tohamy et al (2006) indicated that using foliar application of nutrients especially by phosphorus, calcium and potassium can improve yield of pepper plants grown under sandy soil conditions during winter season.

Regarding to soil mulch treatment, it was obvious that, the increase in pod yield by usage polyethylene mulch is due to its benefits when using soil covering i.e. increases soil temperature, especially in early spring, reduces weed problems, enhances moisture conservation, increases crop yields and leads to more efficient use of soil nutrients (Berihun, 2011; Bhatt et al 2011; Hatami et al 2012; Kumar and Lal, 2012). On the other hand, sulphur is important for good vegetative growth leading to a high yield and increasing absorption of macro and micronutrients. This is through its oxidation to sulphuric acid by soil microorganisms leading to the solubilization and availability of nutrients to plants crops.(Marschner, 1998; Salem, 2003 and Salem et al 2004).

\section{III- Chemical properties}

Data in Table (5) show that adding charcoal to the soil before sowing snap bean seeds followed by adding charcoal + sulphur treatment produced pods contained the highest values of protein and $\mathrm{N}$ percentage. Concerning total sugars it's clear that using protection plants by broad bean followed by onion were the best treatments. This result are in agreement with those mentioned by Abdel-Aziz and Gaafer (2013); Dahmardeh et al (2010) and Eskandari et al (2012). These results may be due to that charcoal helps and allow better uptake of nutrients and fertilizers added to the soil. Studies have shown significant increases in the availability of all major cations as mention by Glaser et al (2002), Topoliantz et al (2005), Graber et al (2010) and Altland and Locke (2012). While, plants sprayed with amcotone compound gave the highest values of $\mathrm{P} \%$ and $\mathrm{K} \%$, in both growing seasons. Regarding to total chlorophyll of leaves, data indicated that, there was no significant effect from using all treatments in both growing seasons. According to agriculture sulphur, it is known that sulphur has an important role in the formation of plant proteins and some hormones, as well as being necessary for enzymatic action, chlorophyll formation, and synthesis of certain amino acids and vitamins (Kundu and Gaur, 1984 and Monib et al 1984).

Table 5. Effect of some agricultural treatments on pod chemical properties and leaf chlorophyll content of snap bean plants during the two seasons of 2012 and 2013

\begin{tabular}{|c|c|c|c|c|c|c|c|c|c|c|c|c|}
\hline \multirow[t]{2}{*}{ Treatments } & \multicolumn{2}{|c|}{$\begin{array}{c}\text { Total } \\
\text { Sugars } \\
\%\end{array}$} & \multicolumn{2}{|c|}{ Protein \% } & \multicolumn{2}{|c|}{$\mathrm{N} \%$} & \multicolumn{2}{|c|}{$\mathbf{P} \%$} & \multicolumn{2}{|c|}{$\mathrm{K} \%$} & \multicolumn{2}{|c|}{$\begin{array}{c}\text { Leaf } \\
\text { chlorophyll } \\
\text { (SPAD) }\end{array}$} \\
\hline & 2012 & 2013 & 2012 & 2013 & 2012 & 2013 & 2012 & 2013 & 2012 & 2013 & 2012 & 2013 \\
\hline Control & 7.80 & 8.20 & 11.81 & 12.56 & 1.89 & 2.01 & 0.42 & 0.45 & 2.15 & 2.18 & 39.83 & 35.16 \\
\hline Flowering & 11.44 & 11.66 & 14.00 & 13.78 & 2.24 & 2.20 & 0.56 & 0.59 & 2.39 & 2.41 & 47.53 & 46.10 \\
\hline Amcotone & 12.42 & 12.86 & 14.88 & 14.44 & 2.38 & 2.31 & 0.63 & 0.62 & 2.49 & 2.52 & 48.00 & 45.03 \\
\hline Super phosphate & 10.84 & 11.06 & 15.09 & 15.12 & 2.41 & 2.42 & 0.61 & 0.61 & 2.31 & 2.36 & 49.26 & 43.55 \\
\hline Mulch & 10.52 & 10.68 & 14.21 & 13.5 & 2.27 & 2.17 & 0.59 & 0.5 & 2.24 & 2.3 & & 43.05 \\
\hline Pea & 12.26 & 11.63 & 14.44 & 14.00 & 2.31 & 2.24 & 0.55 & 0.56 & 2.26 & 2.27 & 45.50 & 41.53 \\
\hline Onion & 12.51 & 12.04 & 12.90 & 13.56 & 2.06 & 2.17 & 0.55 & 0.53 & 2.31 & 2.35 & 45.16 & 41.98 \\
\hline Broad bean & 13.03 & 13.41 & 12.69 & 13.14 & 2.03 & 2.10 & 0.56 & 0.60 & 2.33 & 2.36 & 44.83 & 41.00 \\
\hline Charcoal & 10.86 & 10.91 & 16.18 & 15.75 & 2.59 & 2.52 & 0.56 & 0.56 & 2.21 & 2.20 & 45.23 & 39.80 \\
\hline Sulphur & 11.01 & 11.05 & 15.53 & 15.31 & 2.48 & 2.45 & 0.58 & 0.56 & 2.18 & 2.24 & 47.18 & 38.35 \\
\hline charcoal+sulphur & 11.41 & 7.97 & 15.75 & 15.75 & 2.52 & 2.52 & 0.58 & 0.57 & 2.23 & 2.27 & 47.66 & 41.10 \\
\hline L.S.D at $5 \%$ & 0.55 & N.S & 0.88 & 1.17 & 0.17 & N.S & 0.07 & 0.09 & 0.16 & 0.15 & N.S & N.S \\
\hline
\end{tabular}




\section{REFERANCES}

Abou El-Yazied, A. and Mady, M.A. 2011. Effect of naphthalene acetic acid and yeast extract on growth and productivity of tomato (Lycopersicon esculentum Mill.) Plants Res. J. Agric. and Bio. Sci., 7(2): 271-281.

Abedel-Aziz, M.A. and Gaafer, M.S. 2013. Some agricultural treatments for protection (Phaseolus vulgaris L.) plants from fluctuation weather conditions and their effects on its production. Egypt . J. of Appl. Sci., 28(3): 140153.

Altland, J.E. and Locke, J.C. 2012. Biochar affects macronutrient leaching from a soilless substrate. Hort Sci. 47: 1136-1140.

A.O.A.C., 1990. Official Methods of Analysis of Association of Official Agricultural Chemists. $15^{\text {th }}$ pp. 1045-1106.

Aslam, M.; Ahmad, E.; Saguu, A.G. and Hussain, K. 2010. Effect of plant growth regulator (NAA) and available soil moisture depletion on yield and yield components of chickpea. Sarhad J. Agric., 26(3): 325-335.

Bai, D.I.S.; Abraham, A.T. and Mercy, S.T. 1987. Hormonal influence of crop performance in green gram. Legume Res., 10(1): 49-52.

Banuelos, G.S.; Bangerth, F. and Marschner, H. 1988. Basipetal auxin transport in lettuce and its possible involvement in actropetal calcium transport and incidence of tipburn. J. Plant Nutr., 11: 525-533.

Berihun, B. 2011. Effect of mulching and amount of water on the yield of tomato under drip irrigation. J. Hort. Forest., 3: 200-206.

Bhatt, L.; Rana, R.; Uniyal, S.P. and Singh, V.P. 2011. Effect of mulch materials on vegetative characters, yield and economics of summer squash (Cucurbita pepo) under rainfed mid-hill condition of Uttarakhand. Veg. Sci., 38: 165168.

Bremner, J.M. and Mulvaney, C.S. 1982. Total nitrogen. In: Pag, A.L., R.H. Miller and D.R. Keeny (Eds). Methods of soil analysis. Part 2, Amer. Soc. Agron. Madison, W.I. USA, pp. 595-624.

Dahmardeh, M.; Ghanbari, A.; Syahsar, B.A. and Ramrodi, M. 2010. Therole of intercroooing maiz (Zea mays L.) and Cowpea (Vigna unguiculata $L$.) on yield and soil chemical properties. African J. Agri. Res., 5(8): 631-636.

Dale, J.E. 1964. Some effects of alternating temperature on the growth of French bean plants. Ann. Bot, 28:127-135.
Deotale, R.D.; Maske, V.G.; Sorte, N.V.; Chimurkar, B.S. and Yerne, A.Z. 1998. Effect of GA and NAA on morphological parameter of soybean. J. Soil Crops. 8(1): 91-94.

Dong, C.X.; Zhou, J.M.; Fan, X.H.; Wang, H.Y.; Duan, Z.Q. and Tang, C. 2005. Application methods of calcium supplements affect nutrient levels and calcium forms in mature tomato fruits. J. Plant Nutrition., 27(8): 1443-1455.

Dubois, M.; Gilles, A.; Hamihon, K.J.; Rebers, P.R. and Smith, P.A. 1975. Achlorimetric methods substances. Anal. Chem., 28: 350356.

El-Tohamy, W.A.; Schnitzler, W.H.; El-Behairy, U.A. and Singer, S.M. 1999. Effect of longterm drought stress on growth and yield of bean plants (Phaseolus vulgaris L.). J. Applied Botany- Angewandte Botanik, 73: 173-177.

El-Tohamy, W.A.; Singer, S.M.; El-Behairy, U.A. and Abou-Hadid, A.F. 2001. Effects of low tunnels, plastic much and mineral nutrient treatments on chilling tolerance of snap bean plants. Acta Hort., 559: 127-134.

El-Tohamy, W.A.; Ghoname, A.A. and AbouHussei, S.D. 2006. Improvement of pepper growth and productivity in sandy soil by different fertilization. J. App. Sci. Res., 2(1): 8-12.

Eskandari, H. 2012. Intercropping of maize (Zea mays L.) with cowpea (Vigna sinensis L.) and mungbean (Vigna radiata L.): Effect of complementary of intercrop components on resource consumption, dry matter production and legumes forage quality. J. Basic. Appl. Sci. Res., 2(1): 355-360.

Glaser, B.; Lehmann, J. and Zech, W. 2002. Ameliorating physical and chemical properties of highly weathered soils in the tropics with charcoal - a review. Biology and Fertility of Soils., 35: 219-230.

Graber, E.R.; Harel, Y.M.; Kolton, M.; Cytryn, E.; Silber, A.; David, D.R.; Tsechansky, L.; Borenshtein, M. and Elad, Y. 2010. Biochar impact on development and productivity of pepper and tomato grown in fertigated soilless media. Plant Soil 337: 481-496.

Halterlein, A.J. 1983. Bean. In: Teare, I.D. and Peet, M.M. (eds). Crop-Water Relations. John Wiley, New York, USA

Hatami, S.; Nourjou, A.; Henareh, M. and Pourakbar, L. 2012. Comparison effects of different methods of black plastic mulching and planting patterns on weed control, water-use efficiency and yield in tomato crops. Int. J. Agric. Sci., 2: 928-934. 
Jackson, M.L. 1967. Soil chemical analysis. Prentic-Hall, India, Private Limited, New Delhi, India.

Kochhar, P.L. and Krishnamoorthy, H.N. 1988. A Text Book of Plant Physiology. McGraw Hill Book Co. Inc., New York, USA.

Kumar, S.D. and Lal, B.R. 2012. Effect of mulching on crop production under rainfed condition: A review. Int. J. Res. Chem. Environ., 2: 820.

Kundu, B.S. and Gaur, A.C. 1984. Rice response to inoculation with N2-fixing and P-solubilizing microorganisms, Plant and Soil, 79(2): 227234.

Marschner, H. 1998. Mineral Nutrition of Higher Plants. Harcourt Brace and Company, London, UK.

Millar, A.A. and Gardner, W.R. 1972. Effects of soil and plant water potential on the dry matter production of snap bean. Agron. J., 64: 559562.

Monib, M.I. Hosny and Besada, Y.B.1984. Seed inoculation of castor oil plant (Ricinus communis) and effect on nutrient uptake. Soil Biology and Conservation of the Biosphere, 79(2): 723-732.

Nonnecke, R.1989. Vegetables Production. Van Nostrand Reinhold. New York, USA.NY.656 pp.

Olsen, S.R. and Sommers, L.E. 1982. Phosphorus. In: Page, A.L.; R.H. Miller and D.R. Keeney) Eds. Methods of soil Analysis Part 2 Amer. Soc. Agron. Madison, W.I. USA., pp. 403-430.

Poincelot, R.P. 1980. Horticulture Principles, Practical Applications. Prentice Hall, Inc. New Jersy, USA. pp. 7632-7652.

Salem, F.S. 2003. Effect of some soil amendment on the clayey soil properties and some crops production. Menoufya. J. of Agric. Res. 28: 1705-1715.
Salem, F.S.; Gebrail, M.Y.; Easa, M.O. and Abd El-Warth, M. 2004. Raising the efficiency of nitrogen fertilization for wheat plants under salt affected soils by applying some soil amendments. Menoufya. J. of Agric. Res., 29: 1059-1073.

Shafeek, M.R.; El-Zeiny, O.A.H. and Ahmed, M.E. 2005. Effect of natural phosphate and potassium fertilizer on growth, yield and seed composition of pea plant in new reclaimed soil. Asian. J. Plant. Sci., 4: 608-612.

Shukla, K.C.; Singh, O.P. and Samaiya, R.K. 1997. Effect of foliar spray of plant growth regulators and nutrient complex on productivity of soybean var. JS. 7981. Crop Res., 13(1): 213 $-215$.

Singer, S.M.; El-Tohamy, W.A.; Abou-Hadid, A.F.; Markhart, A.H. and Li, P.H. 1996. Chilling and water stress injury in bean (Phaseolus vulgaris L.) is reduced by pretreatment with $\mathrm{CaCl}$, mefluidide, $\mathrm{KCl}$ and $\mathrm{MgCL}$. Egypt. J. Hort., 23: 77-87.

Snedecor, C.W. and Cochran, W.G. 1982. Statistical Methods. $7^{\text {th }}$ Ed. The lowa State Univ. Press. Ames. lowa, USA. pp. 325-330.

Suty, L. 1984. Growth regulator and potential of faba bean. Cultivar. pp. 171: 71-73.

Topoliantz, S.; Pong, J.F. and Ballof, S. 2005. Manioc peel and charcoal: a potential organic amendment for sustainable soil fertility in the tropics, Biology and Fertility of Soils, 41: 1521.

Tukry, N.S.M.A. 2007. Physiological studies on snap bean. M.Sc. Thesis, Fac. Agric., Cairo Univ., Egypt. pp. 22-69.

Wen, F.Y.; Sun, D.L.; Ju, P.H.; Su, Y.M. and An, Z.X. 1991. Effect of NAA on calcium absorption and translocation and prevention of tipburn in Chinese cabbage. Acta Hort., 18: 148-152. 